\title{
Aberrant right subclavian artery and right-sided ductus arteriosus
}

\author{
Farhad Bakhtiary, ${ }^{1}$ Ingo Dähnert, ${ }^{2}$ Martin Kostelka ${ }^{1}$ \\ ${ }^{1}$ Department of Cardiac Surgery, University of Leipzig, Heart Centre, Leipzig, Germany \\ ${ }^{2}$ Department of Paediatric Cardiology, University of Leipzig, Heart Centre, Leipzig, Germany \\ Correspondence to Farhad Bakhtiary, farhad@bakhtiary.de
}

\section{DESCRIPTION}

A premature newborn weighing $1.9 \mathrm{~kg}$, presenting with cyanosis, feeding and respiratory difficulties was admitted to our centre for further evaluation. An initial echocardiogram suggested a pulmonary atresia with a malalignment infundibular ventricle septum defect with atypical right-sided ductus arteriosus $(2.4 \mathrm{~mm})$ arising from the aberrant right subclavian artery $(4 \mathrm{~mm})$, which was originating from the left-sided descending aorta. The right ductus arteriosus was connected to a small central pulmonary bifurcation (2-3 $\mathrm{mm})$. Intravenous prostaglandin E1 was initiated. A cardiac catheterisation revealed a relevant left to right shunt and normal coronary anatomy. A left ventriculography and an aortogram demonstrated a left aortic arch with two branches arising from it - the first being truncus brachiocephalicus followed by the left common carotid artery. The aberrant right subclavian artery originating from the left-sided descending aorta was communicated through a right patent ductus arteriosus with the pulmonary bifurcation (figure 1). Surgical treatment included a left-sided modified Blalock-Taussig shunt ${ }^{1}$ with resection of ductus arteriosus.

The case describes an unusual vascular ring ${ }^{2}{ }^{3}$ with pulmonary atresia and ventricular septal defect. The only source of pulmonary blood flow was a right-sided persistent ductus arteriosus, which originated from an aberrant right subclavian artery.

Competing interests None.

Patient consent Obtained.

Figure 1 Aortogram (anterior posterior view): left-sided descending aorta, which is temporary occluded, aberrant right subclavian artery (arteria lusoria) originating from the descending aorta communicating through a right-sided ductus arteriosus with pulmonary bifurcation as the only source for pulmonary flow. 


\section{BMJ Case Reports}

\section{REFERENCES}

1. de Leval MR, McKay R, Jones M, et al. Modified Blalock-Taussig shunt. Use of subclavian artery orifice as flow regulator in prosthetic systemic-pulmonary artery shunts. J Thorac Cardiovasc Surg 1981;81:112-19.

2. McKay R, Stark J, de Leval M. Unusual vascular ring in infant with pulmonary atresia and ventricular septal defect. Br Heart J 1982;48:180-3.
3. Edwards JE. Retro-esophageal segment of the left aortic arch, right ligamentum arteriosum and right descending aorta causing a congenital vascular ring about the trachea and esophaguw. Mayo Clin Proc 1948;23:108-16

This pdf has been created automatically from the final edited text and images.

Copyright 2010 BMJ Publishing Group. All rights reserved. For permission to reuse any of this content visit

http://group.bmj.com/group/rights-licensing/permissions.

BMJ Case Report Fellows may re-use this article for personal use and teaching without any further permission.

Please cite this article as follows (you will need to access the article online to obtain the date of publication).

Bakhtiary F, Dähnert I, Kostelka M. Aberrant right subclavian artery and right-sided ductus arteriosus. BMJ Case Reports 2010; 10.1136/bcr.04.2010.2937, date of publication

Become a Fellow of BMJ Case Reports today and you can:

Submit as many cases as you like

Enjoy fast sympathetic peer review and rapid publication of accepted articles

Access all the published articles

Re-use any of the published material for personal use and teaching without further permission

For information on Institutional Fellowships contact consortiasales@bmjgroup.com

Visit casereports.bmj.com for more articles like this and to become a Fellow 